\title{
Characterization and taxonomic placement of Rhizoctomia-like endophytes from orchid roots
}

\author{
X. C. Shan \\ E. C. Y. Liew \\ M. A. Weatherhead \\ I. J. Hodgkiss ${ }^{1}$ \\ Department of Ecology $\mathcal{E}^{\circ}$ Biodiversity, The University \\ of Hong Kong, Pokfulam Road, Hong Kong
}

\begin{abstract}
Twenty-one Rhizoctonia-like fungal strains were isolated from the roots of four terrestrial orchid species from various locations in Hong Kong. The cultural morphology, nuclear number of the hyphal cell, pore ultrastructure, and RAPD and CAPS analyses of rDNA fragments revealed that most of these isolates were associated with the genera Ceratorhiza and Epulorhiza. RAPD analysis showed the presence of genetic diversity between the isolates from different hosts and locations. The compatibility between a selection of these Ceratorhiza and Epulorhiza isolates and 14 orchid species was determined using a symbiotic germination method. The germination and development of three orchid species, Arundina chinensis, Spathoglottis pubescens, and Spiranthes hongkongensis, were strongly stimulated by the Epulorhiza isolates. Habenaria dentata was found to form symbionts successfully with a Ceratorhiza isolate.
\end{abstract}

Key Words: Ceratorhiza, Epulorhiza, mycorrhiza, orchid, pore ultrastructure, Rhizoctonia, ribosomal DNA, symbiont

\section{INTRODUCTION}

It has long been established that under natural and horticultural conditions, there exists an association between orchid roots and certain species of fungi (Hadley 1982). Such an orchid-fungus relationship is formed at the onset of seed germination. Orchid seeds are relatively minute and lack sufficient food reserves, so their germination depends on the external supply of nutrients from compatible fungi. The isolation and identification of orchid mycorrhizal fungi are thus of importance to the understanding of the orchid-fungus relationship.

Most orchid mycorrhizal fungi have been assigned

Accepted for publication August 27, 2001.

' Corresponding author, Email: hodgkiss@hkucc.hku.hk to the form genus Rhizoctonia (Sneh et al 1991). The genus represents an assemblage of taxonomically diverse groups that differ in many features, including anamorph and teleomorph stages (Curtis 1939, Warcup and Talbot 1966, 1967, 1980, Gurrah et al 1987). Most species in this genus are mycelis sterilia and a variety of approaches have been developed to identify them. The conventional method of identifying these Rhizoctonia fungi has been based on their cultural morphology, which includes colony color, monilioid cells, sclerotia, and other mycelium characteristics (Curtis 1939, Currah et al 1987). Anastomosis group (AG) based on anastomosis behavior of vegetative hyphal fusion and intraspecific group (ISG) within AGs based on combined evidence from anastomosis behavior, pathogenicity, morphology, and other criteria have been the most frequently adopted methods to identify $R$. solani complex and study their genetic diversity (Vilgalys and Cubeta 1994). Ramsay et al (1987) assigned some Australian orchid Rhizoctonia-like endophytes to five anastomosis groups. However, DNA data showed that while most AGs represent monophyletic evolutionary units, hyphal anastomosis behavior may not be the best indication of evolutionary relationship between different ISGs (Vilgalys and Cubeta 1994).

Moore (1987) assigned doliporous Rhizoctonia and Rhizoctonia-like fungi into the groups Ceratorhiza, Epulorhiza and Monilioipsis according to the cell nuclear number and septum ultrastructural features. This framework has been adopted by several other researchers recently when identifying orchid mycorrhizal fungi because it offers a taxonomically correct and justified approach to define taxa. Species concepts within these genera can then be erected on the basis of finer culture characteristics such as mycelia morphology on specific media (Currah et al 1990, Currah and Zelmer 1992, Zelmer and Currah 1995, Andersen 1996).

The use of DNA fingerprinting techniques has proved to be a useful, fast and accurate approach to the study of variations among inter- and intraspecific strains in many fungi complexes (Cubeta and Vilgalys 1997, Sen et al 1999). Random amplified polymorphic DNA (RAPD) analysis surveys multiple loci of the whole genome simutaneously with each single primer and detects nucleotide differences between 
TABLE I. Sources of Rhizoctonia-like isolates studied in this investigation

\begin{tabular}{|c|c|c|c|c|c|}
\hline Orchid species & Habitat & Location & $\begin{array}{l}\text { No. of } \\
\text { root } \\
\text { specimens }\end{array}$ & $\begin{array}{c}\text { Fungal } \\
\text { accession no. }\end{array}$ & Collection time \\
\hline Eulophia flava & $\begin{array}{l}\text { Exposed grassy hill- } \\
\text { side }\end{array}$ & $\begin{array}{l}\text { Lamma Island, Hong } \\
\text { Kong }\end{array}$ & 10 & Eu3 & $\begin{array}{l}\text { July } 1996 \text { (after } \\
\text { flowering) }\end{array}$ \\
\hline \multirow[t]{3}{*}{ Goodyera procera } & $\begin{array}{l}\text { Rocky banks of } \\
\text { streams }\end{array}$ & $\begin{array}{l}\text { Ma On Shan, Kowloon } \\
\text { peninsula }\end{array}$ & 10 & $\begin{array}{l}\text { G23, G38, G44, } \\
\text { G45, G46, G47, } \\
\text { G48 }\end{array}$ & $\begin{array}{l}\text { April 1996, April } \\
1997\end{array}$ \\
\hline & & $\begin{array}{l}\text { Shing Mun, Kowloon } \\
\text { peninsula }\end{array}$ & 10 & $\begin{array}{l}\text { G13, G15, G16, } \\
\text { G17, G19, G20, } \\
\text { G29 }\end{array}$ & March-April 1996 \\
\hline & & $\begin{array}{l}\text { Tai Po Kau, Kowloon } \\
\text { peninsula }\end{array}$ & 5 & G55 & March 1996 \\
\hline Habenaria dentata & $\begin{array}{l}\text { Exposed grassy hill- } \\
\text { side }\end{array}$ & $\begin{array}{l}\text { Sai Kung, Kowloon } \\
\text { peninsula }\end{array}$ & 10 & $\begin{array}{l}\mathrm{H} 29, \mathrm{H} 30, \mathrm{H} 31, \\
\quad \mathrm{H} 34\end{array}$ & April 1997 \\
\hline $\begin{array}{l}\text { Spiranthes hongkon- } \\
\text { gensis }\end{array}$ & $\begin{array}{l}\text { Damp but sunny } \\
\text { hillside }\end{array}$ & $\begin{array}{l}\text { Ma On Shan, Kowloon } \\
\text { peninsula }\end{array}$ & 10 & Spir36 & May 1996 \\
\hline
\end{tabular}

isolates. The analysis of restriction fragment length polymorphisms (RFLP) and cleaved amplified polymorphic sequences (CAPS) of DNA (Drenkard et al 1997) in general can provide information on a few specific loci in the genome, thus reflecting the relationships between isolates in a relatively more conservative way than RAPD. These techniques have been widely employed to distinguish subspecific groups of Rhizoctonia solani and showed similar patterns of variations within and among ISGs (Vilgalys and Gonzalez 1990, Duncan et al 1993, Vilgalys and Cubeta 1994, Matsumoto et al 1996, Cubeta and Vilgalys 1997), but very few studies have been carried out to determine the genetic relationships among orchid Rhizoctonia-like endophytes and identify them on the basis of molecular characteristics, pore ultrastructure, and number of nuclei in combination (Andersen 1996, Sen et al 1999).

In the present study, morphological characteristics and the number of nuclei of all strains, and pore ultrastructure of some strains of orchid endophytes were investigated to segregate them into groups. RAPD and CAPS analyses were undertaken in order to understand the genetic relationships among the orchid-associated Rhizoctonia-like isolates from different geographic locations and hosts in Hong Kong. An attempt was made to establish the relationship between our isolates and reference strains of Rhizoctonia at the genetic level in order to identify the isolates from orchids. The compatibility between seeds of several orchid species and a selection of the fungal strains was tested for any correlation between symbiont-forming ability and specific groupings of these strains.

\section{MATERIALS AND METHODS}

Sources of isolates.-Endophytic fungi were isolated from roots of four terrestrial orchid species Eulophia flava, Goodyera procera, Habenaria dentata, and Spiranthes hongkongensis. Only Rhizoctonia-like fungi (21 isolates) were selected for culturing based on the characteristics described by Sneh et al (1991). Their sources are listed in detail in TABLE I.

Five fungal strains identified to species level were used as references. They were Ceratorrhiza cornigerum (Bourdot) Rogers (ATCC 34054, USA), C. globisporum Warcup \& Talbot (CBS 569.83, The Netherlands), Rhizoctonia repens Bernard (CBS 298.32), R. solani Kühn (CBS 174.83), and Thanatephorus cucumeris (Frank) Donk (CBS 233.93).

Sampling procedure and isolation of endophytes.- Soil was carefully removed from the orchid plants, keeping the roots intact. Healthy roots were rinsed under running tap water and surface sterilized in $70 \%$ ethanol for $5 \mathrm{~s}$, then transferred to $0.1 \% \mathrm{HgCl}_{2}$ for $1-5 \mathrm{~min}$ and rinsed in five changes of distilled water. The roots were then aseptically cut into approximately $2 \mathrm{~mm}$ portions and placed singly in $5 \mathrm{~cm}$ Petri dishes containing Potato Dextrose Agar (PDA, Difco) with $3 \mathrm{mg} / \mathrm{L}$ rose bengal and $50 \mathrm{mg} / \mathrm{L}$ streptomycin (Sig$\mathrm{ma})$. The plates were incubated in the dark at $25 \mathrm{C}$ until hyphae were visibly growing from root specimens onto the medium. Pure cultures were then obtained by transferring hyphal tips onto PDA. All cultures were incubated at $25 \mathrm{C}$ in the dark.

Culture of isolates and induction of teleomorph.-Besides PDA, isolates were also grown on Cornmeal agar (CMA, Difco) and Oatmeal agar (2.5\% oatmeal flakes, OMA) at $25 \mathrm{C}$ in the dark to observe the cultural characteristics. Some cultures were left for at least $6 \mathrm{wk}$ to allow the development of monilioid cells and the formation of sclerotia. For the observation of nuclei number and hyphal morphology, isolates were grown on dialysis membranes placed 
on CMA. Cultures were kept on PDA at $4 \mathrm{C}$ or in sterilized distilled water at room temperature for long term storage.

To induce teleomorph formation, the media employed were PDA, CMA, CMA with orchid leaf-discs, OMA, water agar (1\% Bacto-agar, Difco) and V-8 agar (Johnston and Booth 1983). Isolates on these media were incubated under near UV-light for $12 \mathrm{~h}$ and darkness for $12 \mathrm{~h}$. All cultures were examined weekly.

The soil-agar method of Stretton et al (1964) was also used to induce sporulation. Isolates were grown on PDA in $9 \mathrm{~cm}$ Petri dishes for $7-10 \mathrm{~d}$. The lids were then removed, and each culture was covered to a depth of approximately $1 \mathrm{~cm}$ with sterilized soil which was watered 1-3 times a day to maintain constant moisture. The cultures were observed over a three-month period.

Cultural characteristics.-Colony surface and reverse colors were determined according to the descriptions in Methuen Handbook of Colour (Kornerup and Wanscher 1978) and coded with the prefix MHC.

The measurements of hyphal diameter and dimensions of monilioid cells were made by examination of the mycelium mounted in lactophenol on microscope slides.

Growth rates were determined according to the technique of Currah et al (1987). A small fragment of mycelium (approximately $1 \mathrm{~mm}^{2}$ ) was inoculated onto the middle of a $9 \mathrm{~cm}$ PDA plate. Radial increments in colony diameter were measured in two directions every $48 \mathrm{~h}$ over a two-week period. Growth rates were represented by averages based on three replications.

Nuclei number of hyphal cells.-Determination of the nuclei number in vegetative cells was carried out by modifying the procedure of Sneh et al (1991) as follows: hyphae growing on the dialysis membrane were fixed in $2 \%$ formaldehyde for $2 \mathrm{~min}$ and rinsed in distilled water for $1 \mathrm{~min}$. Hyphae were then stained with $5 \mu \mathrm{g} / \mathrm{ml}$ of $4^{\prime}-6^{\prime}$-diamidino-2-phenylindole (DAPI) for $10 \mathrm{~min}$, and destained with water for 2 min. The material was finally placed in a drop of $50 \%$ glycerine on a microscope slide. A cover slip was used without pressing down onto the hyphae.

All micrographs were made using an Olympus BX60 microscope equipped with an Olympus fluorescence accessory with mercury lamp.

Transmission electron microscopy (TEM).--Isolates examined were grown on PDA for $7 \mathrm{~d}$ and then TEM work was carried out following the methods of Wong et al (1998).

Preparation of genomic DNA.--Each isolate was grown on PDA for $15-30 \mathrm{~d}$ at $25 \mathrm{C}$. A $0.25 \mathrm{~cm}^{2}$ piece of mycelium was then scraped from the surface of the plate for DNA extraction. DNA was extracted according to the protocols described by Doyle and Doyle (1987), and Bult et al (1992) with the following modifications:

Mycelium was ground in $2 \times$ CTAB buffer and incubated at $60 \mathrm{C}$ for $25-30 \mathrm{~min}$. After extraction with $2 / 3$ volume phenol: chloroform: isoamyl alcohol (25:24:1), the sample was extracted 2-3 times using chloroform: isoamyl alcohol (24:1) until the aqueous layer was clear. The aqueous layer was then precipitated in 2 volumes cold absolute ethanol $(-20 \mathrm{C})$ for $2 \mathrm{~h}$, centrifuged and the supernatant discarded.
TABLE II. Primers used in RAPD analysis

\begin{tabular}{cl}
\hline \hline Primer & Sequence $\left(5^{\prime}-3^{\prime}\right)$ \\
\hline UBC-016 & GGT GGC GGG A \\
UBC-031 & CCG GCC TTC C \\
UBC-034 & CCG GCC CCA A \\
UBC-065 & AGG GGC GGG A \\
UBC-066 & GAG GGC GTG A \\
UBC-070 & GGG CAC GCG A \\
UBC-071 & GAG GGC GAG G \\
UBC-073 & GGG CAC GGG A \\
UBC-089 & GGG GGC TTG G \\
UBC-091 & GGG TGG TTG C \\
\hline
\end{tabular}

The DNA pellet was dissolved in TE buffer with $0.8 \mu \mathrm{g} / \mathrm{mL}$ RNaseA stock ( $10 \mathrm{mg} / \mathrm{mL}$, Promega) and stored at $4 \mathrm{C}$.

DNA amplification with random primers (RAPD).-The RAPD protocol described by Liew and Irwin (1994) was followed with slight modification. Each polymerase chain reaction (PCR) was performed in a total volume of $25 \mu \mathrm{L}$. The reaction mixture consisted of approximately $30 \mathrm{ng}$ template DNA, $2.5 \mu \mathrm{L} 10 \times$ Taq DNA polymerase buffer (Promega), $4 \mathrm{mM} \mathrm{MgCl}_{2}$ (Promega), $200 \mu \mathrm{M}$ of each dNTP, 1 unit of Taq polymerase (Promega), $0.5 \mu \mathrm{M}$ primer (Set \#1, Nucleic Acid-Protein Service Unit, University of British Columbia, Canada) and MilliQ water. Mineral oil (30 $\mu \mathrm{L}$, Promega) was overlaid on the reaction mixture. A PTC-100 Programmable Thermal Controller (MJ Reaearch Inc.) was programmed for $5 \mathrm{~min}$ at $94 \mathrm{C}$, followed by 40 cycles of 1 $\min$ at $94 \mathrm{C}, 1 \mathrm{~min}$ at $37 \mathrm{C}$, and $2 \mathrm{~min}$ at $72 \mathrm{C}$. The final cycle was followed by an extension step for $8 \mathrm{~min}$ at $72 \mathrm{C}$.

Template DNA was amplified using 10-base primers. Ten primers were used and their sequences are listed in TABLE II. A control sample $(C$. cornigerum $\times$ primer UBC-065) was included in each PCR run. The amplified products were separated by electrophoresis in $1.5 \%(\mathrm{w} / \mathrm{v})$ agarose gels $\left(\mathrm{G}_{\mathrm{IB}} \mathrm{BRL}\right)$ in Tris Borate (TBE) buffer containing $0.3 \mu \mathrm{g} /$ $\mathrm{mL}$ ethidium bromide (EtBr), at $2.5 \mathrm{~V} / \mathrm{cm}$. The gels were visualized and photographed on a uv-transilluminator.

PCR amplification of the ribosomal DNA.--The internal transcribed spacers (ITS1 and ITS2), the 5.8S subunit and partial $18 \mathrm{~S}$ subunit of the ribosomal DNA defined by the primers NS5 and ITS4 were amplified by PCR according to White et al (1990). Primer NS5 is located in the 18S rDNA region and ITS4 is located in the $28 \mathrm{~S}$ rDNA region.

PCR amplification was performed in a reaction mixture with a final volume of $50 \mu \mathrm{L}$. The mixture contained 50 $100 \mathrm{ng}$ of genomic DNA, $300 \mathrm{pM}$ each of both primers NS5 and ITS4, $5 \mu \mathrm{L} 10 \times$ Taq DNA polymerase buffer (Promega), $1.5 \mathrm{mM} \mathrm{MgCl}_{2}$ (Promega), $200 \mu \mathrm{M}$ of each dNTP, 1.5 unit of Taq polymerase (Promega). Mineral oil $(30 \mu \mathrm{L}$, Promega) was overlaid onto the reaction mixture. The reaction was performed in a PTC-100 ${ }^{\text {TM }}$. Programmable Thermal Controller (MJ Reaearch Inc.) for 31 cycles of: denaturation at $95 \mathrm{C}$ for $1 \mathrm{~min}$, annealing at $52 \mathrm{C}$ for $50 \mathrm{~s}$, and extension at $72 \mathrm{C}$ for $1 \mathrm{~min} 20 \mathrm{~s}$, with an initial denaturation of $3 \mathrm{~min}$ at $95 \mathrm{C}$ before cycling and a final extension of 15 
min at $72 \mathrm{C}$ after cycling. A fraction $(5 \mu \mathrm{L})$ of the PCR products was size fractioned in a $0.8 \%$ agarose gel $\left(\mathrm{G}_{\mathrm{IB}} \mathrm{BRL}\right.$, Spain) with $0.3 \mu \mathrm{g} / \mathrm{mL} \mathrm{EtBr}$. The presence of a single bright band (ca $1.3 \mathrm{~kb}$ ) for each sample indicated successful amplification. The remaining PCR product was purified and concentrated using Wizard ${ }^{\mathbb{M}}$ PCR Preps Purification System (Promega) for restriction enzyme digestion.

Restriction of PCR-amplified fragments.-PCR-amplified products were digested using restriction endonucleases, DpnII, EcoRI, HaeIII, HpaII and RsaI (New England Biolabs, Inc.), as recommended by the manufacturer. The digestion products were separated by electrophoresis in a $2 \%$ agarose gel $\left(\mathrm{G}_{\mathrm{IB}} \mathrm{BRL}\right)$ containing $0.3 \mu \mathrm{g} / \mathrm{mL}$ EtBr in TBE, at $2.5 \mathrm{~V} / \mathrm{cm}$. The DNA size marker used in this experiment was a 100 base-pair ladder (Pharmacia Biotech).

Data analysis.-The data from RAPD and restriction of PCR-amplified fragments were scored for the presence or absence of bands at each size location, designated 1 or 0 respectively. The data matrices were analyzed by the SIMQUAL program of NTSYS-PC, version 1.8 (Rohlf 1994). The similarity index $(\mathrm{F})$ between two individuals $\mathrm{x}$ and $\mathrm{y}$ was calculated based on the theory of Nei and Li (1979) using the formula $\mathrm{F}=2 \mathrm{~m}_{\mathrm{xy}} /\left(\mathrm{m}_{\mathrm{x}}+\mathrm{m}_{\mathrm{y}}\right)$, where $\mathrm{m}_{\mathrm{xy}}$ was the number of bands shared by the two individuals $\mathrm{x}$ and $\mathrm{y}$, and $\mathrm{m}_{\mathrm{x}}$ and $\mathrm{m}_{\mathrm{y}}$ were the numbers presented by the individuals $\mathrm{x}$ and $\mathrm{y}$, respectively. A phenogram based on the data matrix was constructed using UPGMA (Unweighted Pair Group Method with Arithmetic Mean) cluster analysis to visualize the relation between the samples.

In this study, differences in band intensity were not taken into account. For a given primer, we assumed fragments amplified from different individuals but which had the same molecular weight to be identical.

Orchid seed collection and sowing.--Seeds of 14 orchid species in dehiscing capsules were obtained from the their natural habitats in Hong Kong, with the exception of those of Phaius tankervilliae which were collected from cultivated plants in the garden of The University of Hong Kong. The 13 wild species were the terrestrial species Arundina chinensis, Cymbidium ensifolium, Eulophia flava, Goodyera procera, Habenaria dentata, H. rhodocheila, Malaxis sp., Paphiopedilum sp., Peristylus tentaculatus, Spathoglottis pubescens, Spiranthes hongkongensis, Zeuxine gracilis, and the epiphytic species Liparis longipes.

All seeds were sown within $24 \mathrm{~h}$ after harvest. Seeds were surface sterilized by suspending them in $0.1 \% \mathrm{HgCl}_{2}$ with $0.1 \%$ of Tween 80 (surfactant) and shaken for 5 min. The seeds were then rinsed in five changes of sterilized water.

Approximately 300 seeds were distributed over the surface of a sterile filter paper strip $(1 \times 3 \mathrm{~cm}$, Whatman No. 1) resting on the surface of an OMA plate (Rasmussen and Rasmussen 1991). An $8 \mathrm{~mm}^{3}$ block of Potato Dextrose Agar (Difco) with or without mycorrhizal fungus was placed at the edge of each filter paper strip in symbiotic and asymbiotic cultures respectively. The plates were then sealed with parafilm and incubated in continuous light of approximately 500 Lux provided by Gro-Lux fluorescent light tubes at a temperature of $25 \mathrm{C}$ (Yam and Weatherhead 1988, An- derson 1991). Three replicates of each treatment were prepared. For seeds that failed to germinate, a dark germination condition was also tried.

One or more fungal strains from different morphological groups were selected to test their ability to form symbionts with orchids. They were Eu3, G16, G19, G38, G55, H30, H34 and Spir36.

Assessment of germination and developmental stages.-Germination (rupture of the seed coat by enlarged embryo) and developmental stages were assessed using a scale of 14 which is adopted from Zettler and McInnis (1993) but modified by combining the stage 3 and 4 as one. Stage 0 : No germination; Stage 1: Enlarged embryo and seed coat rupture, occasionally a rhizoid present; Stage 2: Embryo 23 times enlarged and rhizoids present; Stage 3: Leaf primordium present and appearance of first true leaves; Stage 4: Elongation of initial leaves and root differentiation.

\section{RESULTS}

Twenty-one Rhizoctonia-like isolates were obtained, Eulophia flava (1), Goodyera procera (15), Habenaria dentata (4), and Spiranthes hongkongensis (1) (TABLE I).

Fungal morphology.-All isolates in the present study can be segregated into four morphological groups (MG) on the basis of their morphological characteristics. TABLE III summarizes the significant features observed in the isolates.

RAPD analysis.- Twenty two fungal isolates (21 orchid endophytes and one a reference and outgroup strain Ceratobasidium cornigerum) were examined. A total of 207 bands were scored for polymorphisms. A phenogram constructed using UPGMA cluster analysis is shown in FIG. 1a. The similarity index between the isolates examined ranges from approximately $18 \%$ to $100 \%$. Six main groups with a similarity index lower than $23 \%$ between each other can be observed. The MG II isolates, which were isolated from Goodyera procera and Eulophia flava, are grouped into two main clusters. The MG IV isolates, which were isolated from Habenaria dentata, form one of the main clusters and show a low level of heterogeneity (similarity index >95\%). The MG I isolate H34, MG III isolate Spir36, and the reference strain C. cornigerum, are assigned to three different main clusters. Among the isolates, H34 is most distantly related to the others.

Isolates that are highly similar were from the same host species and location. For example, G13, G15, G16, G17, G19, and G29 from Shing Mun show similar RAPD patterns and have similarity indices of above $95 \%$. However, not all of the isolates from the same host species and location show a high level of similarity. G20 from Shing Mun is distinct from the 
TABLE III. Summary of cultural, morphometric characteristics of Rhizoctonia-like isolates (all characteristics were observed on PDA except where otherwise indicated)

\begin{tabular}{|c|c|c|c|c|}
\hline & Group I & Group II & Group III & Group IV \\
\hline $\begin{array}{l}\text { Color of young colony } \\
\text { (surface) }\end{array}$ & $\begin{array}{l}\text { Yellowish to white } \\
\text { (MHC 4A2-4A3) }\end{array}$ & White (MHC 1A1) & $\begin{array}{l}\text { Grey to greyish yellow } \\
\quad(\text { MHC 2B1) }\end{array}$ & $\begin{array}{l}\text { Yellowish white } \\
\text { (MHC 2A1) }\end{array}$ \\
\hline $\begin{array}{l}\text { Color of young colony } \\
\text { (reversed })\end{array}$ & $\begin{array}{l}\text { Butter yellow (MHC } \\
\text { 4A4-4A5) }\end{array}$ & $\begin{array}{l}\text { Milk to pale yel- } \\
\text { low (MHC 1A1- } \\
\text { 1A2) }\end{array}$ & $\begin{array}{l}\text { Yellowish grey (MHC } \\
\text { 4B2) }\end{array}$ & $\begin{array}{l}\text { Yellow grey (MHC } \\
\text { 4B2) }\end{array}$ \\
\hline $\begin{array}{l}\text { Change in colony col- } \\
\text { or at } 4 \mathrm{C}\end{array}$ & No & No & No & Yes \\
\hline Colony appearance & Cottony & Glabrous or fluffy & Flat or felted & Glabrous \\
\hline $\begin{array}{l}\text { Color of vegetative hy- } \\
\text { phae }\end{array}$ & Hyaline & Hyaline & Hyaline & Hyaline \\
\hline $\begin{array}{l}\text { Diameter of vegetative } \\
\text { hyphae }(\mu \mathrm{m})\end{array}$ & $3.8-7.5$ & $1.8-5.0$ & $1.8-5.0$ & $1.8-5.0$ \\
\hline $\begin{array}{l}\text { Shape of monilioid } \\
\text { cells (if present) }\end{array}$ & $\begin{array}{l}\text { Ellipsoidal or elongate } \\
\text { barrel shape }\end{array}$ & $\begin{array}{l}\text { Irregularly ellipsoi- } \\
\text { dal to nearly } \\
\text { spherical }\end{array}$ & Absent & Nearly spherical \\
\hline $\begin{array}{l}\text { Dimension of moni- } \\
\text { lioid cells }(\mu \mathrm{m})\end{array}$ & $\begin{array}{l}(7.5-15.0) \times(10.0- \\
25.0)\end{array}$ & $\begin{array}{l}(7.5-20.0) \times(7.5- \\
12.5)\end{array}$ & Absent & $\begin{array}{l}(3.8-6.3) \times(3.8- \\
7.5)\end{array}$ \\
\hline $\begin{array}{l}\text { Color of sclerotial mas- } \\
\text { ses on OMA }\end{array}$ & $\begin{array}{l}\text { White to yellowish } \\
\text { (MHC 2A1) }\end{array}$ & White (MHC 1A1) & White (MHC 1A1) & White (MHC 1A1) \\
\hline $\begin{array}{l}\text { Colony growth rate } \\
(\mathrm{mm} / \mathrm{hr})\end{array}$ & $0.42-0.52$ & $0.14-0.36$ & $0.14-0.16$ & $0.08-0.12$ \\
\hline $\begin{array}{l}\text { Septal structure (only } \\
\text { some strains were } \\
\text { examined) }\end{array}$ & Not determined & $\begin{array}{l}\text { Dolipore septa, } \\
\text { imperforate par- } \\
\text { enthesome } \\
\text { (Eu3, G16, and } \\
\text { G19) }\end{array}$ & $\begin{array}{l}\text { Dolipore septa, imper- } \\
\text { forate parenthesome } \\
\quad(\text { Spir36) }\end{array}$ & Not determined \\
\hline Nuclear condition & Binucleate cells & Binucleate cells & Binucleate cells & Binucleate cells \\
\hline Teleomorph & Absent & Absent & Absent & Absent \\
\hline Material examined & H34, ATCC 34054 & $\begin{array}{l}\text { Eu3, G13, G15, } \\
\text { G16, G17, G19, } \\
\text { G20, G23, G29, } \\
\text { G38, G44, G45, } \\
\text { G46, G47, G48, } \\
\text { G55, CBS } \\
298.32\end{array}$ & Spir36 & H29, Н30, H31 \\
\hline
\end{tabular}

other Shing Mun isolates, and is assigned to another main group. Isolates from the same host species but different locations show a high level of heterogeneity and are separated into distinct clusters. For example, although G16, G38, and G55 are all from Goodyera procera, the similarity index between G16 (from Shing Mun) and G38 (from Ma On Shan) is approximately 48\% while G16 (from Tai Po Kau) clustered within a separate main group from that of G16 and G38.

CAPS analysis of ITS1, ITS2, 5.8S, and part of the $18 \mathrm{~S}$ $r D N A$.-Eleven orchid endophytes were chosen for the CAPS study on the basis of RAPD results. Most of the selected isolates are heterogeneous according to the RAPD data, except G16 and G29 which are similar (FIG. 1a). Five strains, Ceratobasidium cornigerum,
C. globisporum, Rhizoctonia repens, $R$. solani, and Thanatephorus cucumeris were included in the study as references.

A total of 71 bands were scored and a phenogram (FIG. 1b) was derived on the basis of UPGMA cluster analysis. The MG II isolates, which were isolated from Eulophia flava and Goodyera procera, show a high level of similarity and were assigned to a distinct cluster with a similarity index of $>60 \%$. Among the reference strains, Rhizoctonia repens shows the closest relationship with the MG II isolates. The MG I isolate H34, Ceratobasidium cornigerum, C. globisporum, and Thanatephorus cucumeris were assigned to one cluster at a $60 \%$ similarity level. In this cluster, H34 is most closely related to C. cornigerum, with a similarity index of approximately $88 \%$. H30 is most dissimilar to all the other strains tested. 
Screen tests for host-fungal compatibility.-Germination and development of Arundina chinensis, Spathoglottis pubescens, and Spiranthes hongkongensis was strongly stimulated by the selected fungal strains in MG II (Eu3, G16, G19, G38, G55) except for G19 which was not tested with $A$. chinensis and which failed to form successful symbionts with $S$. hongkongensis (TABLE IV). Strains in other morphological groups could not enhance germination and development of these three orchid species.

A few seeds of $L$. longipes and $P$. tankervilliae developed to seedling stage (stage 4) with some MG II strains such as Eu3. Germination and development of seeds of $H$. dentata was strongly stimulated by H34 in MG I only (TABLE IV).

No fungal strain selected in the tests formed successful symbionts with the other eight orchid species studied (TABLE IV). G16, G19, G38, G55 from G. procera and Spir36 from $S$. hongkongensis all failed to stimulate germination of the seeds of the orchid species from which they had been obtained.

\section{DISCUSSION}

Moore (1987) assigned anamorphic binucleate $R h i$ zoctonia species with dolipore septa and perforate parenthesomes to the genus Ceratorhiza, with the teleomorph Ceratobasidium. In our study, although septal ultrastructure of H34 in morphological group I (MGI) was not determined, the high similarity between H34 and Ceratobasidium cornigerum (ATCC 34054) indicated by CAPS analysis suggests that H34 could be assigned to the group of the anamorphic genus Ceratorhiza. Besides the close genetic relationship, the morphology of this strain is also similar to that of C. cornigerum in this study and that of Ceratorhiza goodyerae-repentis described by Richardson, Currah and Hambleton (1993).

The type species of Ceratorhiza, Ceratorhiza goodyerae-repentis (Constantin and Dufour) Moore was initially described by Constantin and Dufour (1920) based on an isolate from Goodyera repens (L.) R. Br. Later, Downie (1941) gave another description of this species in detail (Andersen and Staplers 1994). Warcup and Talbot (1966) determined that Rhizoctonia (Ceratorhiza) goodyerae-repentis was an anamorph of Ceratobisidium cornigerum by inducing fruiting bodies from a $R$. goodyerae-repentis isolate identified according to the concept of Downie (Hadley 1969, Andersen and Staplers 1994). This species has been commonly obtained from either terrestrial or epiphytic orchid mycorrhizas in Australia and Britain (Warcup and Talbot 1967, Warcup 1981, Alexander and Hadley 1983), Canada (Currah et al 1990, Currah and
Zelmer 1992), Costa Rica (Richardson et al 1993) and Malaya (Hadley and Williamson 1972).

Moore (1987) seggregated binucleate Rhizoctonia species with dolipore structure and imperforate parenthesomes to the genus Epulorhiza, with teleomorphs Tulasnella and Waitae (Sneh et al 1991). According to Moore's classification (1987), isolates Eu3, G16, and G19 in MG II and isolate Spir36 in MG III can be identified as Epulorhiza species. The RFLP analysis of rDNA fragments showed a relatively high level of similarity between isolates of Eu3, G16 and the other isolates in MG II. This result suggests that all the isolates in MG II may belong to the form genus Epulorhiza. The similarity of morphological characteristics between isolates of MG II and those of Rhizoctonia (Epulorhiza) repens and Tulasnella sp. (described by Warcup and Talbot 1980, Currah et al 1987), and the genetic closeness of these isolates to Rhizoctonia (Epulorhiza) repens shown by rDNA CAPS analysis further support the above classification.

The type species of Epulorhiza, Epulorhiza repens (Bernard) Moore, was first described by Bernard (1909) based on isolates from Laelio-Cattleya Canhamiana. Curtis (1939) named a group of isolates from seven orchid species as $R$. repens Bernard according to the cultural morphology, especially the morphology of monilioid cells that were similar to those Bernard had illustrated. Warcup and Talbot (1967) induced teleomorph from $R$. repens isolates and identified it as Tullasnella calospora.

Fungi in the genus Epulorhiza are distinct and have been continuously isolated from orchids (Hadley 1982, Currah et al 1990, 1997, Currah and Zelmer 1992, Zelmer et al 1996). For example, Marchisio et al (1985) described some orchid endophytes in Italy, which can be placed in Epulorhiza according to the reassignment of Moore (1987). Currah et al (1987) isolated E. repens from some terrestrial orchids in $\mathrm{Al}$ berta, Canada and described the morphology in detail. Some researchers suggest that Epulorhiza endophytes may be common to all species of Spiranthes (Masuhara and Katsuya 1994, Zelmer and Currah 1997). The identification of Spir36 here also shows there is a relationship between Spiranthes hongkongensis and the genus Epulorhiza.

Both the RAPD and rDNA CAPS analyses show that MG IV isolates are highly dissimilar to all the other strains examined. Since septal ultrastructures of the isolates in this group was not determined, the MG IV isolates are tentatively assigned to the genus Rhizoctonia.

Andersen (1996) reported that RFLP patterns, pore ultrastructure, and sclerotial morphology of $\mathrm{Cer}$ atorhiza (Ceratobasidium anamorph) strains were not distinct from Moniliopsis (Thanatephorus anamorph) 


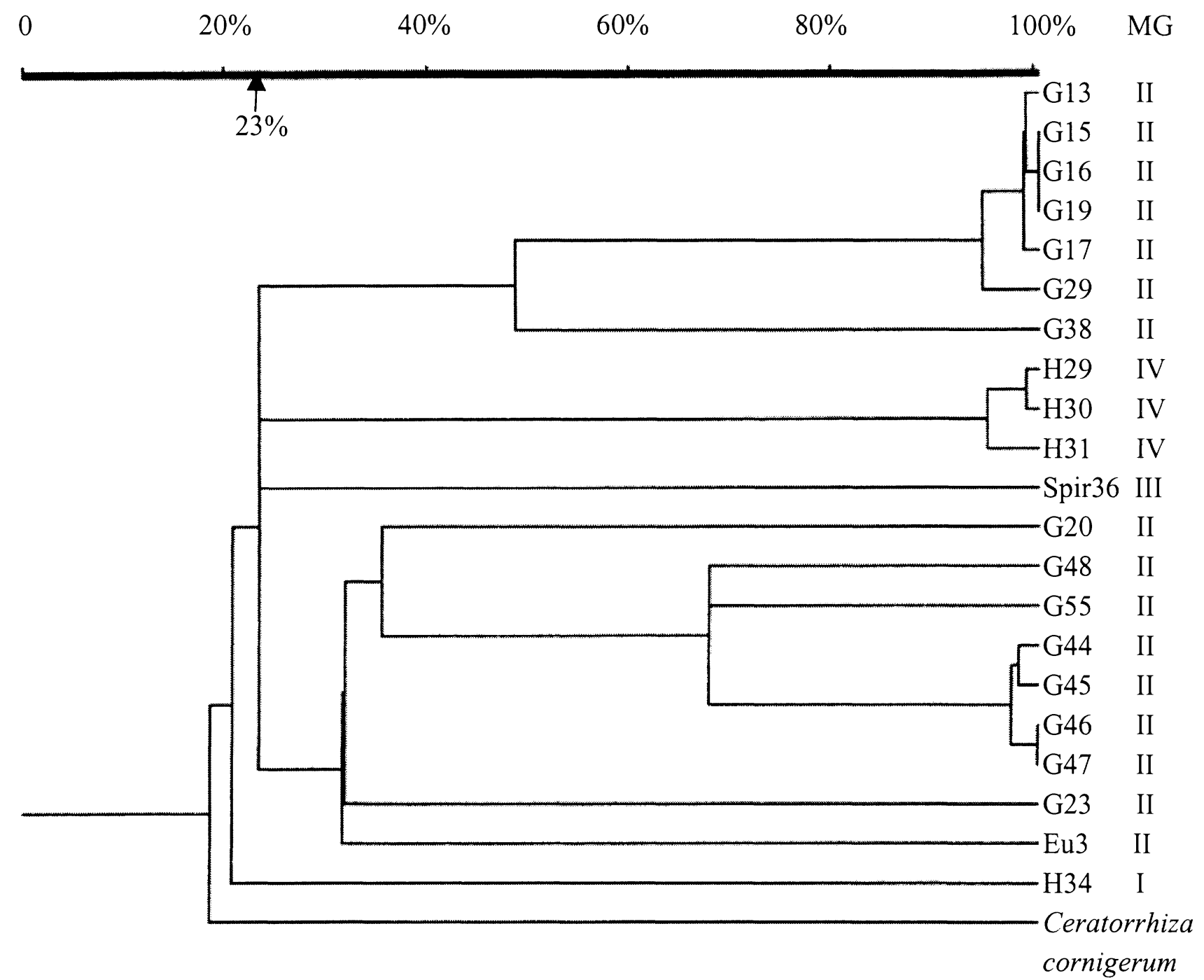

FIG. 1a. Phenogram showing the genetic similarity between Rhizoctonia-like isolates based on RAPD analysis.

strains. Earlier studies of sclerotial morphology (Tu and Kimbrough 1975, 1978) also showed a close relationship between Ceratobasidium and Thanatephorus anamorph. On the basis of rDNA CAPS analysis presented here, Thanatephorus is again considered to be close to Ceratobasidium.

Among the Epulorhiza species, only strains from morphological group II (MG II) showed strong ability to stimulate germination and development of some orchid seeds. CAPS patterns showed that there were close genetic relationships between these Epulorhiza species. The morphological group I (MGI) strain could stimulate seeds of only one orchid species to plantlet stage. This indicates that a specific group of fungi may be required by some orchid species during their germination and early development. And CAPS analysis is likely to have the potential to help us to find compatible mycorrhizal fungi for these orchids rapidly.
Some fungal isolates from roots of Goodyera procera and Spiranthes hongkongensis could not enhance seed germination of their hosts. However, the isolates from $G$. procera could form successful symbionts with seeds of other orchids such as Spathoglottis pubescens. One explanation for this phenomenon is that the fungal symbionts required by the adult orchid plants (or any intervening stage) may not necessarily be the same as those required for germination (Warcup 1973, Smericu and Currah 1989, Zelmer and Currah 1997). Another explanation is that the orchid plants were infected by several fungi at the same time and those endophytes we obtained were not the ones forming symbionts with their hosts.

In conclusion, it has been shown that DNA analysis can be used to provide molecular data to delineate Rhizoctonia strains at generic and sub-generic levels, especially when morphological characteristics are taken into account. In the current study, RAPD analysis 
Similarity index

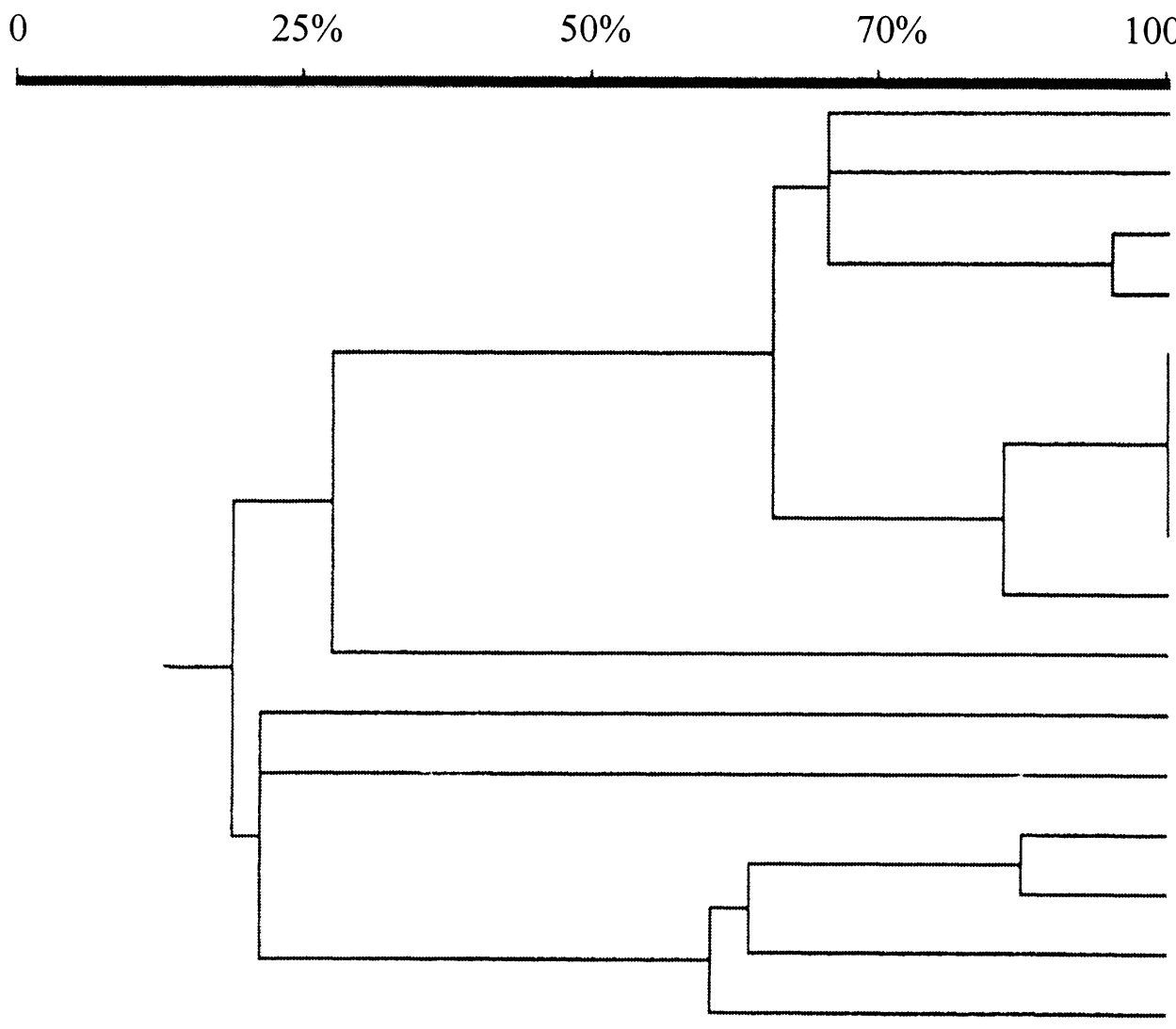

$100 \% \quad \mathrm{MG}$

- G38 II

Eu3 II

G48 II

G16 II

G20 II

G23 II

G45 II

G55 II

G29 II

Rhizoctonia repens

H30 IV

R. solani

H34 I

Ceratorrhiza cornigerum

C. globisporum

\section{Thanatephorus cucumeris}

FIG. 1b. Phenogram showing the genetic similarity between Rhizoctonia-like isolates and some reference strains based on CAPS analysis.

TABLE IV. Germination and development of various orchid seeds on OMA medium with or without test fungal strain ${ }^{\mathrm{a}}$

\begin{tabular}{|c|c|c|c|c|c|c|c|c|c|}
\hline Orchid species & $\begin{array}{c}\text { No } \\
\text { fungal } \\
\text { strain }\end{array}$ & Eu3 & G16 & G19 & G38 & G55 & H30 & H34 & Spir36 \\
\hline Arundina chinensis & 2 & 4 & 4 & $-^{\mathrm{b}}$ & 4 & 4 & 2 & 2 & 2 \\
\hline Cymbidium ensifolium & 0 & 0 & 0 & 0 & 0 & 0 & 0 & 0 & 0 \\
\hline Eulophia sinensis & 0 & 0 & 0 & 0 & 0 & 0 & 0 & 0 & 0 \\
\hline Goodyera procera & 0 & 0 & 0 & 0 & 0 & 0 & 0 & 0 & 0 \\
\hline Habenaria dentata & 1 & 2 & 2 & 2 & 2 & 2 & 2 & 4 & 1 \\
\hline H. rhodocheila & 0 & 0 & 0 & 0 & 0 & 1 & 0 & 0 & 0 \\
\hline Liparis longipes & 0 & $4^{* c}$ & $4 *$ & - & - & - & 一 & - & - \\
\hline Malaxis sp. & 2 & 2 & 3 & - & - & - & - & - & - \\
\hline Paphiopedilum sp. & 0 & 0 & 0 & 0 & 0 & - & - & - & 0 \\
\hline Peristylus tentaculatus & 0 & 0 & 0 & 0 & 0 & 一 & 0 & - & 0 \\
\hline Phaius tankervilliae & 1 & $4^{*}$ & 1 & - & 1 & 1 & 0 & 0 & 0 \\
\hline Spathoglottis pubescens & 3 & 4 & 4 & 4 & 4 & 4 & 3 & 0 & 3 \\
\hline Spiranthes hongkongensis & 0 & 4 & 4 & 1 & 4 & 4 & - & - & 0 \\
\hline Zeuxine gracilis & 1 & 2 & 2 & 2 & 2 & 2 & 2 & 0 & 2 \\
\hline
\end{tabular}

a Numbers refer to the stage of germination and development.

b Not tested.

c* Only one or a few seeds germinated to the stage. 
on all isolates grouped the isolates according to their overall genetic similarity. The sample of strains in the CAPS analysis was then reduced to a smaller one by selecting the representative isolates within a high similarity group. By matching CAPS patterns and morphological characteristics, some isolates were then identified to generic level. Although the septal ultrastructure was not determined for all the isolates in this study, the combination of RAPD and CAPS analyses demonstrated the possibility of identifying some of the isolates relatively rapidly, and indicated the genetic variation between the isolates within the same genera. It is suggested that a more thorough and conclusive identification of these orchid endophytes would require DNA sequence analyses and phylogenetic inferences.

\section{ACKNOWLEDGMENTS}

We gratefully acknowledge Dr. W. H. Ho for technical assistance in TEM work, Dr. J. C. Huang for assistance in data analysis, and Dr. K. Hyde, Dr. R. H. Currah, Ms. C. D. Zelmer and Dr. L. D. Guo for helpful suggestions in fungal identification. We also thank The University of Hong Kong for providing studentship to X. C. Shan.

\section{LITERATURE CITED}

Alexander C, Hadley G. 1983. Variation in symbiotic activity of Rhizoctonia isolates from Goodyera repens mycorrhizas. Trans Br Mycol Soc 80:99-106.

Andersen TF. 1996. A comparative taxonomic study of $R h i$ zoctonia sensu lato employing morphological, ultrastructural and molecular methods. Mycol Res 100: 1117-1128.

Andersen TF, Staplers JA. 1994. A check-list of Rhizoctonia epithets. Mycotaxon 51:437-457.

Anderson AB. 1991. Symbiotic germination and growth of Spiranthes magnicamporum (Orchidaceae). Lindleyana 6:183-186.

Bernard N. 1909. L'evolution dans la symbiose des orchidées et leur champignons commensaux. Annales des Sciences Naturelle Paris 9:1-196.

Bult C, Kallersjo M, Suh Y. 1992. Amplification and sequencing of 16/18S rDNA from gel-purified total plant DNA. Plant Molecular Biology Reporter 10:273-284.

Constantin J, Dufour L. 1920. Sur la biologie du Goodyera repens. Rev Gen Bot 32:529-533.

Cubeta MA, Vilgalys R. 1997. Population biology of the Rhizoctonia solani complex. Symposium of Population Genetics of Soilborne Fungal Plant Pathogens. USA.

Currah RS, Sigler L, Hambleton S. 1987. New records and new taxa of fungi from the mycorrhizae of terrestrial orchids of Alberta. Can J Bot 65:2473-2482.

Currah RS, Smreciu EA, Hambleton S. 1990. Mycorrhizae and mycorrhizal fungi of Plantanthera and Coeloglossum (Orchidaceae). Can J Bot 68:1171-1181.

Currah RS, Zelmer CD. 1992. A key and notes for the gen- era of fungi mycorrhizal with orchids, and a new species in the genus Epulorhiza. Rep Tottori Mycol Inst 30: 43-59.

Currah RS, Zettler LW, McInnis TM. 1997. Epulorhiza inquilina sp. nov. from Platanthera (Orchidaceae) and a key to Epulorhiza species. Mycotaxon 61:335-342.

Curtis JT. 1939. The relationship of specificity of orchid mycorrhizal fungi to the problem of symbiosis. Amer J Bot 26:390-399.

Doyle JJ, Doyle JL. 1987. A rapid DNA isolation procedure for small quantities of fresh leaf tissue. Phytochem Bull 19:11-15.

Downie DG. 1941. Notes on the germination of some British orchids. Trans Bot Soc Edin 33:94-103.

Drenkard E, Glazebrook J, Preuss D, Ausubel FM. 1997. Use of cleaved amplified polymorphic sequences (CAPS) for genetic mapping and typing. In: Caetano-Anolles G, Gresshoff PM, eds. DNA Markers: Protocols, Applications, and Overview. New York: Wiley-Liss. p 187-198.

Duncan S, Barton J, O'Brien P. 1993. Analysis of variation in isolates of Rhizoctonia solani by random amplified polymorphic DNA assay. Mycol Res 97:1075-1082.

Hadley G. 1969. Cellulose as a carbon source for orchid mycorrhiza. New Phytol 68:933-939.

Hadley G. 1982. Orchid mycorrhiza. In: Arditti J, ed. Orchid biology-reviews and perspectives II. Comstock: Cornell University Press. p 85-115.

Hadley G, Williamson B. 1972. Features of mycorrhizal infection in some Malayan orchids. New Phytol 71:11111118.

Johnston A, Booth L. 1983. Plant Pathologists Pocketbook. England: Commonwealth Agricultural Bureau.

Kornerup A, Wanscher JH. 1978. Methuen Handbook of Colour. London: Methuen.

Liew ECY, Irwin JAG. 1994. Comparative studies on Phytophthora megasperma isolates from chickpea collected in Australia and Spain. Mycol Res 98:1284-1290.

Marchisio VF, Berta G, Fontana A, Mannina FM. 1985. Endophytes of wild orchids native to Italy: their morphology, caryology, ultrastructure, and cytochemical characterization. New Phytol 100:623-641.

Masuhara G, Katsuya K. 1994. In situ and in vitro specificity between Rhizoctonia spp. and Spiranthes sinensis (Persoon) Ames. Var. amoena (M. Bieberstein) Hara (Orchidaceae). New Phytol 127:711-718.

Matsumoto M, Furuya N, Takanami Y, Matsuyama N. 1996. RFLP analysis of the PCR-amplified 28S rDNA in Rhizoctonia solani. Mycoscience 37:351-356.

Moore RT. 1987. The genera of Rhizoctonia-like fungi: Ascorhizoctonia, Ceratorhiza gen. nov., Epulorhiza gen. nov., Monilliopsis, and Rhizoctonia. Mycotaxon 29:9199.

Nei M, Li WH. 1979. Mathematical model for studying genetic variation in terms of restriction endonucleases. Proc Natl Acad Sci USA 76:5269-5273.

Ramsay RR, Sivasithamparam K, Dixon KW. 1987. Anastomosis groups among Rhizoctonia-like endophytic fungi in Southwestern Australia Pterostylis species (Orchidaceae). Lindleyana 2:161-166.

Rasmussen HN, Rasmussen FN. 1991. Climatic and seasonal 
regulation of seed plant establishment in Dactylorhiza majalis inferred from symbiotic experiments in vitro. Lindleyana 6:221-227.

Richardson KA, Currah RS, Hambleton S. 1993. Basidiomycetous endophytes from the roots of neotropical epiphytic orchidaceae. Lindleyana 8:127-137.

Rohlf FJ. 1994. Numerical taxonomy and multivariation analysis system. Exeter Software. New York: Saetauket.

Sen R, Hietala AM, Zelmer CD. 1999. Common anastomosis and internal transcribed spacer RFLP groupings in binucleate Rhizoctonia isolates representing root endophytes of Pinus sylvestris, Ceratorhiza spp. from orchid mycorrhizas and a phytopathogenic anastomosis group. New Phytol 144:331-341.

Smreciu EA, Currah RS. 1989. Symbiotic germination of seeds of terrestrial orchids of North America and Europe. Lindleyana 4:6-15.

Sneh B, Burpee L, Ogoshi A. 1991. Identification Of Rhizoctonia Species. St Paul, Minnesota: APS Press.

Stretton HM, McKenzie AR, Baker KF, Flentjie NT. 1964. Formation of the basidial stage of some isolates of $R h i$ zoctonia. Phytopathology 54:1093-1095.

Tu CC, Kimbrough JW. 1975. Morphology, development, and cytochemistry of the hyphae and sclerotia of species in the Rhizoctonia complex. Can J Bot 53:22822296.

- - 1978. Systematics and phylogeny of fungi in the Rhizoctonia complex. Bot Gaz 139:454-466.

Vilgalys R, Cubeta MA. 1994. Molecular systematics and population biology of Rhizoctonia. Annu Rev Phytophathol 32:135-155.

, Gonzalez D. 1990. Ribosomal DNA restriction fragment length polymorphisms in Rhizoctonia solani. Molecular Plant Pathology 80:151-158.
Warcup JH. 1973. Symbiotic germination of some Australian terrestrial orchids. New Phytol 72:387-392.

. 1981. The mycorrhizal relationship of Australian orchids. New Phytol 87:371-381.

Warcup JH, Talbot PHB. 1966. Perfect states of some Rhizoctonias. Trans Br Mycol Soc 49:427-435.

- 1967 . Perfect states of Rhizoctonias associated with orchids. New Phytol 66:631-641.

- -1980 . Perfect states of Rhizoctonias associated with orchids. III. New Phytol 86:267-272.

White TJ, Bruns TD, Lee S, Taylor JW. 1990. Amplification and direct sequencing of fungal ribosomal RNA gene for phylogenetics. In: Innis MA, Gelfand DH, Sninsky JJ, White TJ. eds. PCR protocols: a guide to methods and applications. San Diego: Academic Press. p 315322.

Wong SW, Hyde KD, Ho WH, Stanley SJ. 1998. Tamsiniella labiosa gen. et sp. nov., a new freshwater ascomycete from submerged wood. Can J Bot 76:332-337.

Yam TW, Weatherhead MA. 1988. Germination and seedling development of some Hong Kong orchids. Lindleyana 3:156-160.

Zelmer CD, Currah RH. 1995. Ceratorhiza penacatena and Epulorhiza calendulina spp. nov.: mycorrhizal fungi of terrestrial orchids. Can J Bot 73:1981-1985.

$\longrightarrow$ - 1997. Symbiotic germination of Spiranthes lacera (Orchidaceae) with a naturally occurring endophyte. Lindleyana 12:142-148.

Zelmer CD, Cuthbertson L, Currah RS. 1996. Fungi associated with terrestrial orchid mycorrhizas, seeds and protocorms. Mycoscience 37:439-448.

Zettler LW, McInnis TM Jr. 1993. Symbiotic seed germination and development of Spiranthes cernua and Goodyera pubescens (Orchidaceae: Spiranthaideae). Lindleyana 8:155-162. 